\title{
MISFIRES OF CROSS-CULTURAL LEGAL COMMUNICATION IN THE PERSPECTIVE OF J. AUSTIN AND J. LANGSHAW AUSTIN
}

\author{
Dear interpreter, no matter what You do, \\ no matter how You try, \\ somewhere sometime \\ You are bound \\ to fall short of excellence. \\ For a reasonable interpreter \\ there is only room \\ between two flexible poles: \\ "highly approvable" and "acceptable" \\ - with no place for "perfect"
}

\author{
Sergey KOROLEV \\ Doctor juris habil., Head of the Comparative Law Department at the State and Law \\ Institute of the Russian Academy of Sciences (Moscow), \\ scientific supervisor and long-standing interpreter at the German-Russian Centre of Legal \\ Studies (Moscow-Muenster). \\ 119991, State and Law Institute, Znamenka str. 10, Moscow \\ sko.05@mail.ru
}

\begin{abstract}
The article is meant to serve both theory and practice in the cross-roads area where legal theory meets linguistic philosophy. The legal perspective is represented by the famous command theory of John Austin, who is often regarded as the founding father of anglo-american branch of legal positivism. The linguistic perspective is represented by the speech acts theory elaborated by John Langshaw Austin.

It is argued that the command theory is only of marginal use for any process of crosscultural legal communication. The reason behind this argument is that the command theory is grossly reductionist in its nature ("colonel - lieutenant") and cannot therefore embrace a trilateral reality of cross-cultural legal communication (speech originator - interpreter - audience). But the imperative theory may be useful if applied to "misfires" of the whole process of legal oral translation. By transforming the said trilateral reality to any dichotomy in the sense of the command theory, i.e. by bracketing together any two of the said agents and by insulating the third one- we inevitably arrive at some sort of "misfire" or even collapse of the whole procedure. Further the common view is challenged that the only source of such "misfires" lies in poor quality of interpretation. It is argued that both the speech originator and even somehow inadequate audience may share the final failure.

The eventual outcome of the article may be described as an attempted synthesis of the speech acts theory of John Langshaw Austin and sociology of law as elaborated by German professor Werner Krawietz. The interdisciplinary approach to discussed "misfires" of cross-cultural legal communication resulted in formulating a series of bilateral rules, which are obligatory both
\end{abstract}




\section{Comparative Legilinguistics 4/2010}

for the speech originator and the interpreter if the most unacceptable "misfires" of legal oral translation are to be avoided.

\section{«ОСЕЧКИ» КРОСС - КУЛЬТУРНОЙ ЮРИДИЧЕСКОЙ КОММУНИКАЦИИ В ПЕРСПЕКТИВЕ ДЖОНА ОСТИНА И ДЖОНА ЛЭНГШО ОСТИНА}

Abstract: Статья носит одновременно теоретический и прикладной характер. В ней предпринята попытка совместить юридическую и лингвистическую перспективу при анализе кросс - культурной юридической коммуникации. Юридическая перспектива представлена императивной теорией Джона Остина - родоначальника англо-американской версии юридического позитивизма. Лингвистическая перспектива представлена теорией речевых актов яркого представителя лингвистической философии Джона Лэнгшо Остина.

Показано, что императивная теория ввиду ее крайне редукционистского характера («начальник - подчиненный») не может полностью охватить характер отношений типа «лектор - переводчик - аудитория». Все три агента являются авторами конечного продукта, т.е. удавшейся лекции. Однако императивная теория полезна при анализе различных редукционистских констелляции, в который один из трех агентов может быть выведен «за скобки» как величина, которою можно пренебречь. Критикуется распространенная точка зрения, что в неудачах юридического перевода всегда повинны переводчики. Нередко они разделяют вину с «носителем первичного текста» и даже с не вполне адекватной аудиторией.

В заключении предпринята попытка конвергенции теории речевых актов Джона Лэнгшо Остина и социологии права в духе Вернера Кравица. Разработаны билатеральные правила устного перевода, которые без ущерба для процесса кросс-культурной юридической коммуникации не могут игнорировать ни носитель первичного текста, ни его переводчик.

This article deals with the so called grey zone in which any legal interpreter may find himself in the process of oral translation of foreign lecture on law. Our main concern is a phenomenon of procedural "misfires" in cross-cultural interaction of national legal cultures, which is likely to take place during oral translation of any foreign lecture. These misfires may have their origin in slightly different meanings of national technical terms (for example, "contract" versus "Vertrag") or in the absence of any reliable analogy for a term to be translated. Thus, the meaning of the term "Zumutbarkeit" may be rendered in Russian only by means of description, not by designation. The difference of some basic principles, which may play similar roles in different legal cultures, may have divergent ideological or metaphysical origins (for example, "rule of law" versus "Rechtsstaat").

There are, of course, many practical difficulties, which fall into the realm of what may be called sociology of legal interpretation. Thus, it may occur - and indeed often does - that the interpreter must stick to the point notwithstanding the fact that the initial speaker is "carried away" into the realm of metaphor and - more or less irrelevant examples.

It is argued that a theoretical base for coping with problems of this kind may be the speech acts theory of John Langshaw Austin. In some respect there is a strong correlation between the said theory and the legal command theory of another and earlier John Austin - the founder of the anglo-american version of legal positivism.

Although this article deals primarily with a theoretical problem of partial crosscultural incongruities, which may confront any legal interpreter, some preliminary remarks of ideological nature would not be altogether out of place. One often alludes to 
intrinsic and more or less obvious subservient features of any oral translation, or interpretation. It is often acknowledged or even taken for granted by interpreters themselves. "We are bound to sing an alien song" - this is what a professional interpreter said to me on one occasion, when quite on the contrary I tried to communicate my sympathy to his vocation. My today`s comment on this remark would be as follows: "Woe is him who cannot prevent his structural alienation from infecting the process of interpretation itself".

The same problem we are likely to encounter if we regard the general attitude to legal oral translation of academic discourse. Not only laywomen and laymen outside legal professions, but also lawyers and lecturers on law tend to regard legal academic interpretation as kind of subaltern activity always open to criticism and suspicion.

This special ("professor-like") arrogance I would like to challenge partly from within, while lending arguments from the scientific legacy of John Austin (1790-1859), who is sometimes regarded as the founder of legal positivism in its Anglo-American version. In this article I would refer to him as Austin "I".

On the other part, I would like to challenge the ontological dualism (the legacy of Platon), which may be pernicious to the process of legal interpretation, if the agents concerned overtly or tacitly confess this sort of philosophical belief. In this part of my endeavor I would like to lend arguments from another Austin (1911 - 1960), who is one of the founder of the so called speech acts theory. I would refer to him as Austin "II".

\section{Command theory and early legal positivism}

I would like to begin with the famous command theory of Austin "I". More specifically, I will try to probe the validity of the Austin's "I" dichotomy "superiors vs. inferiors" which lends itself to be part of a legal interpretation theory. At least we may regard this dichotomy as a rough conceptual base for any relevant interaction between the speech originator and the interpreter. Moreover, let us accept the possible correlation between the dichotomy "speech originator vs. interpreter" on the one hand, and the juxtaposition "master - apprentice", or even "colonel vs. lieutenant", on the other ${ }^{1}$.

There are at least three aspects of Austin's "I" life and his intellectual background, which may be useful for our brief research:

i. $\quad$ influence of his teacher Jeremy Bentham

ii. his brief life episode as a military officer

iii. his (tacit) identification of law and (political) might

We have to reduce the Bentham's theoretical legacy to his famous principle of utility $^{2}$, which is but the pragmatic consequence of the main axiom of utilitarianism ("mankind is placed under the governance of two sovereign masters, pain and pleasure"). According to this initial axiom human beings inevitably try to minimize anything leading

${ }^{1}$ One influential philosopher was almost cynical in his assessment of translators and interpreters when he said, that all original texts are produced by great minds, but these texts are always to be translated by small minds.

${ }^{2}$ Bentham 1789 


\section{Comparative Legilinguistics 4/2010}

to pain and to maximize anything leading to pleasure. Despite the initial duality (pain versus pleasure) utilitarianism is monistic in its instrumental dimension: it is solely pleasure, or happiness that counts with the notion of pain serving as a contrastive term to, or the logical negation of the dominant criterion of pleasure.

It is worth noting that in this perspective the term "utilitarian legislation" would be an utter tautology, because according to Bentham there is no foundation for rational legislation beyond the boundaries of the principle of utility. Moreover the term "utilitarian legislation" is synonymous with the term "law" as such making the term "natural law" void of any meaning and instrumentality. Natural law doctrines eo ipso lose not only their value "pretensions" but also their content and sense.

It is in this anti-natural law bias that the influence of Jeremy Bentham is mostly felt in the writings of John Austin "I". It is the human legislator, i.e. a legislative body who is the sole sovereign having the authority to determine what is the sum total of human happiness (individually as well as collectively) and how this happiness is to be achieved. Abstract natural law principles have no say in this endeavor. Translating this original Bentham`s approach into realities of military life Austin "I" found out that there remains only one instrument worth sticking to if we are serious enough about the utilitarian goal, and this instrument is a command.

Through Bentham's influence Austin's "I" command theory may be regarded as a reductionist relapse beyond John Locke`s constitutionalism. Like Hobbes both Bentham and Austin "I" confess voluntarism as a motivation force of any human legislation. No wonder that Austin's "I" command theory has little in common with the Rule of Law principle. ${ }^{3}$ Public government strictly speaking is not subject to law. The government agencies use law as an instrument of power in the first place, not as an instrument of "justice" or other natural law concepts.

Against this conceptual background we may now lean ourselves trying to transplant the Austin's "I" command theory into a legal interpretation context. The main concern for us is legal academic interpretation and more specifically the process of consecutive translation of lectures on legal subjects. Legal interpretation may be defined here as a set of interactions between the primary agent, or the speech originator and the secondary agent, or interpreter.

It is obvious, that Austin's "I" command theory may be understood as a series of tacit commands of the speech originator addressed to the interpreter who is bound to meet the originator`s tacit expectations. But there is always another sort of the speech originator expectations, which aim at the audience. Thus, two different sets of the speech originator expectations are always at play, although they are often of different importance to the speech originator himself.

In one case more attention may be attached to the "quality" of the interpreter. In another case the "quality" of the audience weighs more heavily in the eyes of the speech originator. As we see in our case, the Austin's "I" assumed bilateral relation between the "superior" (officer) and the "inferior" (soldier) is inevitably transformed into a trilateral relation (the speech originator - the interpreter - the audience). In any case the audience as such is likely to preserve the black box characteristics even if the speech originator

${ }^{3}$ Cotterell 2003, 70 
makes attempts to establish and maintain some sort of feedback with individual representatives of the audience.

Although there is no way to eliminate this black box feature of the audience altogether, it is the interpreter - not the "defective" audience - often a target of the speech originator critique if no proper contact with the audience is established. This critique often makes sense if the initially established contact with the audience is constantly diminishing. And this disconnection between the poor impact of the interpretation and the high quality of the original speech holds on despite the certitude of the speech originator that the audience was always carried away just at this stage of his presentation.

But if we approach this problem rationally it becomes obvious that the axiom "the interpreter is always to blame" does not hold water. In any trilateral interaction each of the three may be initially responsible for any such failure. Again this responsibility may be of alternate nature: either the interpreter (which is, of course, most often the case) or the audience or - alas! - the speech originator himself has to stand up for the poor outcome. In the most disastrous case the responsibility may be of cumulative, or collective nature: each of the three agents of this sort of communication may fail actual expectations of the other two.

At this stage of our investigation we have to make further corrections of the Austin's "I" command theory. We come to a paradoxical and - for legal positivists perhaps - absurd question: Does a term "sovereign", or "superior" make sense in our trilateral interaction process?

If this question must be answered in the affirmative, then we are bound to ask another question: How should we locate this sovereign? If the sovereign is the speech originator - as Austin "I" himself would have it - then again at least three insurmountable difficulties remain:

1. What commands of the speech originator can "call to order" an obviously mismatched interpreter? For example, how can an English professor of law "control" a highly skilled Russian interpreter who notwithstanding his general qualification lacks the knowledge of technical terms either in Legal English, or Legal Russian or both? Even if the English professor in our case knows some legal terms in Russian, it will be of no use to improve the overall quality of translation even at the expense of the interpreter's reputation...

2. How can a young master of law in his function as a speech originator control his elder interpreter who is good both at general and legal interpretation, because he is professor of law in his own country and is years ahead of his counterpart as a scientific researcher? In some respect this is an inversion of the previous case: it is the speech originator, not the interpreter, who may be a "mismatch" here...

3. How can the speech originator have the audience at his command, if we regard the process of interpretation as a rational interaction flow in the first place and consequently put aside such factors as "charisma", "psychological subjugation" etc.?

Now we may conclude, that there is no place for the notion of sovereign or superior within the legal interpretation process. All depends on the circumstances of the individual case. In many cases the speech originator is or at least thinks to be a 


\section{Comparative Legilinguistics 4/2010}

"sovereign" of the whole process. In other cases it may be the "capricious" audience, which dominates the speech originator. ${ }^{4}$ In not so exceptional and- I would say - critical cases the interpreter would take the lead, for example, in order to save the whole endeavor from the impending disaster.

So we can find alternative and more appropriate terms in sociology of law. They are "interaction system" or "cross-cultural communication system", the latter being the matrix of the first. We may coin an abbreviation for the second term (the system of $3 \mathrm{Cs}$ ). In other words we may find lots of various interaction systems (IS) within the more prolonged and institutionalized system of 3Cs.

Conclusion $\mathrm{Nr}$ 1: Only reliable functioning of the system of $3 \mathrm{Cs}$ counts with all three "subjects" (the speech originator - the interpreter - the audience) submerged and depersonalized in it.

Conclusion Nr 2: The term "command" makes some sense only on the level of the whole system, but it is more appropriate to use the neutral term "rule" instead.

Rule Nr 1 of the system of 3Cs: The interpreter may not substitute the speech originator in principle.

Rule Nr 2 of the system of 3Cs: The speech originator may not substitute the interpreter in principle, either.

Rule Nr 3 of the system of 3Cs: With two unknown quantities (the interpreter + the audience) the "interpreter risk" tends to be more crucial than the "audience risk" for the speech originator. Hence a reasonable speech originator would adapt himself to the intellectual horizon and the specific style of the actual interpreter with only marginal heed to the "intellectual horizon" of the audience.

Rule Nr 4 of the system of 3Cs: With two unknown quantities(the speech originator+ the audience) the "speech originator risk" tends to be more crucial than the "audience risk" for the interpreter. Hence a reasonable interpreter would adapt himself to the intellectual horizon and the specific style of the actual speech originator with only marginal heed to the "intellectual horizon" of the audience.

Rule Nr 5 of the system of $3 \mathrm{Cs}$ : If the interaction system "the speech originator the interpreter" is successfully established, the factor "audience" loses most of its initial relevance.

Rule Nr 6 of the system of 3Cs: Any rupture of the interaction system "the speech originator - the interpreter" may drastically spiral up the "audience risk" which may result in the final miscarriage of the whole endeavor.

\section{Speech acts theory and misfires of oral legal communication}

Let us now try the speech acts theory of Austin "II". He begins with an analysis of the conventional statement theory, with its distinction between

i. true statements and

ii. false statements. ${ }^{5}$

${ }^{4}$ By the way it is not inevitable that the interpreter follows the speech originator in his servility towards the audience.

${ }^{5}$ Austin J.L. 1962 
According to the initial presumption of Austin "II" neither all possible utterances may be called "statements" in the proper sense, nor the distinction between "true" and "false" is always intended by the speaker in the first place. This initial presumption is then presented by Austin "II" in the dichotomy:

i. constatives and

ii. performatives.

Constatives have to designate or describe facts, so constatives may be true or false. Performatives are "speaker-centered" action-utterances, like promises, bets, damnations, congratulations etc. Any meaningful constative both makes sense and has a reference. The constative "His son is bald" makes sense but if he happens to have no son in fact, this constative has no meaning.

If we stick to this Austinian distinction, it becomes clear that many abstract legal terms (for example, the English fiction of a reasonable person or the German principle of Menschenwuerde, or human dignity) may be criticized as being void of meaning. Here we are confronted with the first procedural misfire of oral legal translation: "The flow of constatives (i.e. statements to the point) acquire performative aspects at the moment where the speech originator uses an abstract term, like "equity", "reasonable person", culpa in contrahendo" etc. But no lecturer on law can do without such highly abstract terms lacking any actual reference. It is impossible for the interpreter to strictly discriminate between constatives and performatives in the target language if this discrimination is not intended in the source language.

It may further occur that all of a sudden the speech originator implants in his constative context a "pure performative", for example changing from the role of a lecturer into that of a judge or a barrister. He may do it quite consciously but without any hint to the interpreter. Thus, the interpreter must be vigilant enough to grasp this sudden change of the course from an object-oriented content of the lecture to the speakeroriented utterance(s).

Here we are confronted with the second procedural misfire of oral legal translation: "The content of a lecture on law to be translated has always two "horizons": a horizon of constatives and a horizon of performatives. But the actual interpreter may not be in position to timely take heed of this sudden change of horizons in the source language. In other words, one never knows which of the two horizons will prevail in the course of oral legal translation."

Moreover, neither the speech originator nor the interpreter may be conscious of that. The interpreter is usually better equipped in linguistics but even so he never knows

i. whether the speech originator is inclined to minimize or - on the contrary - to maximize production of performatives and

ii. whether he has a rational plan to timely switch from constatives to performatives during the course of his lecture and vice versa.

The lecture in fact may be structured around a set of performatives, each initiating a more or less prolonged series of constatives. However, more often a performative may be used as a closing remark or a clarifying example of a series of constatives. 


\section{Comparative Legilinguistics 4/2010}

In his later research Austin "II" found out that it is almost impossible to strictly differentiate between the constatives and performatives and he further elaborated his initial dichotomy into a version of speech acts theory. In this theory he discriminates three types of utterances:

i. locutions (object-centered utterances)

ii. illocutions (speaker-centered utterances) and

iii. perlocutions (audience-centered utterances).

According to Austin"II" almost any utterance may have three dimensions simultaneously. For example, the utterance "There is some difference between the rule of law principle and the principle of "Rechtsstaat" (=locution) may be easily transformed into "I insist that there is some difference between the rule of law principle and the principle of "Rechtsstaat" (=illocution) and into "You can not challenge the fact that there is some difference between the rule of law principle and the principle of "Rechtsstaat" (=perlocution).

Almost any defect of the utterance at its "locutionary level" may infect both its illocutionary and perlocutionary levels. The complicated interaction between the source language and the target language in oral legal translation may further aggravate or - on the contrary - heal this situation. Thus, in many "normal checks" and "minor misunderstandings" between the speech originator and the interpreter it is not the interpreter, who is always to blame, although he is rightly presumed to be so.

The content of the originator's speech is likely to make sense to the public if and only if at least two preconditions are met:

i. The speech originator`s assumptions about the scope of motivation and mental capacity of the audience do not "misfire", i.e. the originator has managed to properly identify motives and expectations of the audience

ii. The speech originator of the legal academic speech is flexible enough to adapt himself and his speech to the projected reasonable wants of the actual audience.

\section{Model rules for oral legal translation}

Rule 1: The process of interpretation needs a short warming up in order to establish an intentional state of mind of the interpreter, or the speech originator centered interpreter`s congeniality (SOCIC).

Rule 2: The SOCIC may need a preliminary casual phase of a speech originator - interpreter interaction for further formal cooperation.

Rule 3: The SOCIC yields the best results if it penetrates the subconscious of the interpreter`s mind.

Rule 4: The SOCIC is secured when the interpreter`s mind has shifted to a light trans-like state.

Rule 5: The items of the source language are restructured by the interpreter as a set of contextual units of the target language.

Rule 6: Each contextual unit of the source language coincides with one or more interpretable units of the target language, they may reduce or - on the contrary - exceed the length of the speech units of the source language. 
Rule 7: The borders of each interpretable unit are fixed by the interpreter, not be the speech originator.

Rule 8: The speech originator and his interpreter interact in such a way, as to mutually adapt the length of the original item of the source language and the corresponding item of the target language.

Rule 9: The interpreter translates the meaning of the interpretable unit. If the term is meaningless, he translates only a more or less approximate "dictionary sense" of the term.

Rule 10: If the interpreter loses the control of the context, he switches from the translation of contextual units to the word-by-word translation, with a reasonable hope that the audience is able to get the meaning all the same despite the rupture of the SOCIC.

Rule 11: The interpreter activates a special feed-back technique in order to restore the SOCIC.

Rule 12: The above-mentioned feed-back technique may amount to a contextual question, meaning to evoke the elucidation of the whole, not the missed part from the speech originator.

\section{Bibiliography}

Austin, John, 1995. The Province of Jurisprudence Determined. W. Rumble (ed.),

Cambridge: Cambridge University Press (first published in 1832).

Austin, J.L. 1962. How To Do Things With Words. Oxford: Clarendon Press.

Bentham, Jeremy (1789/1996), An Introduction to the Principles of Morals and

Legislation. J. H. Burns \& H.L.A. Hart, eds., Oxford: Oxford University Press

(first published in 1789).

Bix, Brian H. 2000. On the Dividing Line Between Natural Law Theory and Legal

Positivism. Notre Dame Law Review 75: 1613-1624.

Cotterell, R. 2003. The Politics of Jurisprudence: A Critical Introduction to Legal

Philosophy. $2^{\text {nd }}$ ed. London: LexisNexis.

Krawietz, W., 1984. Recht als Regelsystem. Wiesbaden: Franz Steiner Verlag. 
Comparative Legilinguistics 4/2010 